Candidate of Pedagogical Sciences, Assistant Professor

(Oleksandr Dovzhenko Hlukhiv National Pedagogical University)

1.zagorodnya69@gmail.com

ORCID: $00 \odot \odot-0 \odot \odot 2-2217-1041$

\title{
EMPIRICAL STUDY ON THE FORMATION OF THE MOTIVATIONAL- PERSONAL COMPONENT OF MASTERS' READINESS TO ENSURE THE QUALITY OF EDUCATIONAL PROCESS IN THE PRESCHOOL EDUCATIONAL INSTITUTIONS
}

\begin{abstract}
The article presents the results of an empirical study of the formation of the motivational and personal component of the readiness to ensure educational process quality in the preschool institution. European integration processes in Ukraine and changes in primary school actualize the problem of the Preschool Education Masters' readiness to ensure the educational process quality in preschool institution. To determine the condition of motivational and personal component formation of RTEQEP of future Masters in the preschool institution a complex of diagnosis methods was chosen. These were chosen according to defined components, criteria and indicators, namely the method of the professional activity motivation study (K. Zamfir in modification A. Reana, N. Badmaievoi), method of definition of I-concept (Campbell SCC method), the location of components RTEQEP in the structure of preschool institutions, and questioning, methods of mathematical statistics. It was found that the motivation for professional activity is the best formed at the Masters level-52\% of respondents testified to the high level; $70 \%$ of Masters do not realize the role of motivation. Masters showed a sufficient and average level of self-concept formation and unclear value orientations and professional needs. The students did not name all the main personal and professional qualities of the preschool institution manager, preferring the moral ones. The majority of Masters revealed the average level of the motivational and personal component formation of readiness to ensure the quality of the educational process in the preschool institutions, which indicates the need to organize and work in order to improve this level.
\end{abstract}

Key words: Masters, motivational and personal component of readiness to ensuring the quality of the educational process in preschool educational institutions, diagnostic methods, criteria, levels of formation.

Introduction. The issue of the high-quality training of specialists for the preschool educational institutions has been actualized by the integration of Ukraine into the European educational space, as well as the changes taking place in the adjacent elementary school sphere (development of new industry standards and implementation of the concept of $\boldsymbol{T h e}$ New Ukrainian School). Future directors are responsible for organizing the educational process in the establishments concerned in the capacity of preschool education managers. Properly organized educational process in the institution guarantees quality of preschool education for children, as well as simple adaptation to the conditions of school education. Readiness of a future manager to ensure the quality of educational process in a pre-school institution is a multicomponent personal characteristic of a specialist. Motivational personal component is the core element concerning this issue.

Analysis of recent research and publications. Among the publications concerned with the issue in question, some deserve special attention. Among those are the following: research by H. Zakorchenna [6] on preparation of students for pedagogical management in pre-school education, the study by S. Vitvytska [2] on theoretical and methodological principles of masters training in the conditions of graduate education, the work by V. Zhihir [7; 8] on peculiarities of professional MA level training of education managers, and the essence and content of professionally important personal qualities of the education manager. L. Zadorozhna-Knyahnytska conducted research on the substantiation of the content and structure of the deontological education manager's competence, organizational and methodological conditions for the deontological training of education managers in higher education institutions $[4 ; 5])$. 
As such, the study by H. Zakorchenna states that the preparation of preschool education pedagogical management is most effectively carried out in specifically organized learning conditions. The process should concentrate on the cognitive activity of future specialists in three aspects. These elements are content that adequately reflects the specificity of the preschool education institution as a systemic object of their professional activity; operation, which includes knowledge of the essence, functional structure, and means of management; and value that reveals personal meaning and stimulates the need for continuous selfimprovement as subjects of management [6:19].

By applying subject, activity, systemic, professional, competence, cultural, and acmeological approaches, S. Vitvytska developed MA-level education managers' professiogram. The researcher singled out the following clusters of components: targetoriented (desire, interest, needs, predispositions, ideals, mindset, and beliefs); basic pedagogical abilities (gnostic, constructive, projective, organizational, communicative, intellectual, expressive, suggestive, and creative competences); activity-practical knowledge, skills, abilities, and competence [2: 30].

Researcher V. Zhihir is convinced that the personal qualities of the education manager, one's ambitions, character and ethical views, are more important in professional management than competence. It is in vain to conduct management guided only by technical and communication skills, to do business right, but to lead people in the wrong direction [7: 5]. The researcher singles out two components in the professional training of education managers, namely professional and personal elements. The personal component includes social and professional qualities. Formation of the professional component of specialist's competence in isolation from versatile personal qualities proves ineffective [8: 114].

Guided by the results of the generalization of the components of deontological competence substantiated by V. Artemov, M. Vasilieva, H. Kertayeva, I. Slyusareva and other researchers, L. Zadorozhna-Knyahnytska outlines value-motivational, cognitive-deontological and technological components in the structure of deontological competence of education managers, noting that their formation in complex reflects the readiness of masters for professional management activity [4: 27]. In addition, the researcher divides organizational and methodological conditions of deontological training of education managers in preschool institutions. They determine general requirements for the management in the process of deontological training, ensuring the implementation of its structural components [5].

Despite the urgency of the issue of preschool education quality and professional training of education managers, currently there is a lack of solid scientific research on the formation of masters' readiness to ensure the quality of educational process in a preschool institution. Thus, the aim of this article is to highlight the state of readiness, in particular its motivational and personal components.

Results and Disscussion. The analysis of a number of studies concerning the issue of training education managers and preschool specialists, in particular, for professional activity, allowed for the distinction of the following components of the readiness of masters to ensure the quality of the educational process in preschool institutions: motivational-personal, cognitive-searching, activity-operational, reflexive-evaluative.

The core element of the structure of the readiness in question is a motivational-personal component. It determines the consciousness and purposefulness of obtaining the necessary professional knowledge, skills and abilities by master students.

The empirical study on the formation of the motivational-personal component of masters' readiness to ensure the quality of educational process in the preschool educational institutions was carried out among students of various institutions of higher education in different regions of Ukraine. The institutions were as follow: the faculty of preschool education of Oleksandr Dovzhenko Hlukhiv National Pedagogical University, faculty of Philology and 
Mass Communications of Mariupol State University, faculty of Preschool, Special and Social Education of Berdyansk State Pedagogical University, pedagogical faculty of Donbass State Pedagogical University, faculty of pedagogy of Rivne State Pedagogical University, and the psychology and pedagogical faculty of Poltava National Pedagogical University, V. H. Korolenko. In total, 544 intra- and extramural masters students took part in the experiment, which included 270 students in the control group and 274 students in the experimental group. The control group consisted of 100 intramural students and 170 extramural students. The experimental group consisted of 106 intramural students and 168 extramural students. Among intramural students, $60 \%$ were working in the field, while in the group of extramural students, $95 \%$ were workers in the education sphere.

To determine the levels of the motivational-personal component of readiness, a set of methods was selected. In accordance with the components, criteria and indicators [3], namely, the method of studying the motivation of professional activity (K. Zamfir's approach modified by A. Rean and N. Badmayeva), and Campbell's Self-Concept-Clarity Scale, the determination of the place of components in the readiness to ensure the quality of educational process in the structure of preschool educational institutions, questionnaires, mathematical statistics method were identified. The application of the methods chosen allowed the researcher to cover all aspects of the investigated motivational-personal component of readiness to ensure the quality of educational process in the preschool education institutions and to determine the levels of its formation among master students.

With regard to the educational activities of MA students, professional motivation was understood as the combination of factors and processes that encourage them to study a future profession. At the same time, the researcher considers professional motivation as serving as an internal driving force for the development of professional competence and, in particular, the acquisition of readiness to ensure the quality of educational process in the preschool institutions.

An analysis of the motivation to conduct professional activity while applying the method by K. Zamfir, modified by A. Rean and N. Badmayeva, allows the following to be stated. According to identified readiness levels, the balance of motives of IM $>$ EPM $>$ ENM and VM $=\mathrm{EPM}>\mathrm{ENM}$ were considered, where internal motivation (IM) is equal to external positive motivation (EPM), or higher than EPM and external negative motivation (ENM), and the external negative motivation is low and close to one. The closer to optimum the motivational complex is, the more active master students are in acquiring the degree, in particular with regard to the content of vocational training. The analysis of questionnaires showed that $52 \%$ of respondents had a high level of motivation to work in their professional field, $26 \%$ exhibited a sufficient level, $9 \%$ had an average level and $13 \%$ had a low level of motivation.

In addition, it was important to ascertain the MA students' level of awareness of the role of motivation as a component of professional orientation in the structure of the readiness to ensure the quality of educational process in preschool educational institutions. For this purpose, it was suggested that participants determined the place of such readiness components as professional orientation, knowledge, personal and professional qualities, professional skills as the core element, the basis of readiness, the integrative component and the factor ensuring the success of preparedness.

The analysis of evaluation sheets leads to the conclusion that the majority of respondents $(70 \%)$ do not understand the role of motivation in the process of their readiness formation.

The third method that was chosen was the self-concept clarity scale that is a general pattern or configuration of self-perception. Self-concept contains the following components: cognitive - an image of one's qualities, abilities, appearance, social significance, etc.; emotional - self-esteem, selfishness, self-destruction, etc.; evaluative-volitional - the desire to 
increase self-esteem, etc. As a prerequisite and the result of social interaction, the self-concept is structured by the real self (the idea of oneself in real time), the ideal self (that is, what one should become, oriented to moral norms), dynamic self (what the person intends to become), and fantastic self (what the subject would want to become, if possible) [1: 609-610].

Taking into account the essence of an individual's self-concept, it should be considered important for the future director prepared to ensure the quality of the educational process in preschool institution to have a high and medium, close to high, self-concept clarity level. The analysis of student questionnaires filled in by MA students showed that $41 \%$ of the respondents presented with averages close to a high level of self-clarity, $35 \%$ presented average levels of self-clarity, while $24 \%$ presented with averages close to low self-clarity level. No respondent presented a high self-clarity level. In general, students presented sufficient and moderate level of self-concept clarity.

The purpose of the questionnaire was to obtain empirical information on the state of formation of the motivation-personal component of the readiness to ensure high quality level of education among future managers of preschool institutions. The particular aim was to identify the motives for obtaining the second higher education in the specialty 012 "Preschool education". Another objective was to determine the level of awareness of the components of professional orientation to ensure the quality of the educational process in the institutions concerned, in particular, motives, value orientations, professional needs, personal and professional qualities necessary to ensure smooth educational process.

An analysis of the students' answers pertaining to the motives of obtaining a master's degree allowed for the construction of the following hierarchy of motives. Obtaining new knowledge in the field of preschool education and professional improvement was chosen by $32 \%$ of participants; $29 \%$ chose acquiring full higher education; $18 \%$ chose the desire to work as a manager of educational institution; love for children and profession was chosen by $6 \%$ of the respondents. Disclosure of creative abilities and potential opportunities was marked by $6 \%$, while another $6 \%$ of participants chose the wish to find a job in a specialty. There were a small number of respondents (3\%) who called the groups of motives for obtaining the master's level of education - cognitive, social, moral, creative, and aesthetic. However, among these motives there were none aimed at changing the organization of preschool education, ensuring the quality of educational process in preschool education institution, or improving domestic preschool education as per European standards.

While answering a question about the professional orientation of the manager of preschool education to ensure the quality of the educational process, a small number of MA students (3\%) gave the following definition of the concept of "professional orientation". They marked it as a stable personality feature guided by the dominant motives that make a person work and motivate one to choose a profession. Respondents called the feature as educational motives, systems of value-evaluative attitude of the person to the profession and to themselves as to the professionals, interests, needs, inclinations, aspirations associated with the professional activity. Among the main components were chosen a positive attitude of the person to the profession, professional suitability, professional interests, values, and readiness for professional activity based on the system of attitudes, beliefs, motives of the person, professional self-consciousness. Only $10 \%$ of the participants highlighted the components of professional orientation correctly - as the motives, needs, values, interests, and ideals. Other students $(87 \%)$ could not name the components of the professional orientation of the preschool education institution manager or gave incorrect answers. They chose managerial skills of the head of the institution; personal qualities - communicative, educational, pragmatic, emotional, tolerance, creativity, innovation, wisdom; different types of competence - professional, social, cultural, civic, informational; components of professional 
competence - personality-motivational theoretical, practical, methodical. Some students listed the motives of the professional activities of the preschool educational institution manager.

Thus, a majority of students proved to have no clear understanding of the professional orientation components necessary for a manager of preschool education to ensure the quality of the educational process.

Respondents listed different motives determining a manager's focus on ensuring the quality of the educational process in the preschool institution. Among them where the following clusters of motives: cognitive, material, social, moral, creative, aesthetic, prestigious (7\% of respondents); material, creative, moral (3\%); internal and external (7\%). Some students mentioned generic aspects that can be applied to a specialist in any field - selfesteem, identification, authority, duty and responsibility to society, group, and individuals; self-development, self-determination and self-improvement, the desire to attain other individuals' approval, procedural-substantive motives $(3 \%)$. Another $3 \%$ of respondents chose improvement of professional competence, skills of solving professional and pedagogical problems, increase in the level of competitiveness of preschool education institutions in the market, and economic motives. The following motives related to ensuring the success of preschool education institutions in the region and included creating a positive image and good reputation of the head of the institution and attracting the attention of as many parents of potential pupils as possible to the institution.

Only $10 \%$ of intramural master students and $27 \%$ of participants of extramural programs named the motives of professional activities related to ensuring the quality of the educational process in preschool institution. They chose promoting the professional growth of teaching staff, self-education of the manager, improving the management skills in the organization of the educational process, providing children with high-quality education, and improving the facilities and resources.

Regarding the value orientation of the preschool institution manager, only a small number of respondents with job experience in the field $(6 \%)$ indicated that they are value-oriented towards public recognition and positive assessment of the work of a preschool education institution. Among other priorities they listed comprehensive development of children, health promotion and satisfaction of their needs, provision of quality education, professional growth of a director/staff, improvement of facilities and resources, as well as making a preschool institution correspondent to modern requirements. The majority of MA students $(80 \%)$ named the following professional-personal qualities and skills: leadership, creativeness, determination, respect to the colleagues, organizational skills, knowledge of foreign languages and information technologies, and competency in solving conflict situations among other characteristics. Some respondents $(6 \%)$ determined the value orientations as a slogan equality, justice, beauty, and truth, while $7 \%$ of students left the question without answer.

Most of the students participating in the research chose the following professional needs of the manager of preschool institutions. Those were general professional needs, namely: competence, constant self-improvement, engagement in self-education and self-realization $(50 \%)$, promoting modern facilities and resources in a preschool institution; being a successful manager $(25 \%)$, high moral standards, being a respectable manager $(13 \%)$, being an authoritative leader, taking care of professional self-development of the teaching staff $(12 \%)$. However, none of the responses were accurate and exhaustive in relation to the professional needs of the manager who strives and is able to ensure the quality of the educational process in pre-school institutions.

The students could not differentiate clearly between personal and professional qualities of the manager of preschool institution. In most instances, those qualities were duplicated or mixed. The complexity of the manifestations of the above qualities should be considered as 
the main reason for such duplication. In addition, it is rather complicated to distinguish between personal and professional issues. The respondents named the following personal qualities as necessary for the manager to ensure the quality of the educational process in a preschool institution. The qualities chosen can be attributed to the following groups: moralrelated - honesty, decency, humanity, respect for colleagues, tolerance, justice, ambition, reliability, tact, love for children, and responsibility; volitional group - purposefulness, discipline, persistence, determination, balance, self-control, and ability to take risks; intellectual cluster - creativity, communication skills, logic and critical thinking, selfcriticism, and good memory. There were also answers in which qualifications were replaced with knowledge, skills or abilities (40\%). Most students preferred moral qualities ( $85 \%$ of respondents); the intellectual cluster was mentioned less often - only in $15 \%$ of responses. The main result that needs to be stated is the fact that future specialists are aware of the necessity of having important personal and professional qualities for the manger.

After summarizing the data and evaluating responses by applying the five-point system, results were obtained regarding the formation of motivational-personal component of readiness to ensure the quality of educational process in the preschool educational institutions among master students. They are reflected in Table 1.

Table 1

Levels of formedness of motivational-personal component of readiness to ensure the quality of educational process in the preschool educational institutions among students at the initial stage of the experiment

\begin{tabular}{|c|c|c|c|c|c|c|c|c|}
\hline Levels & \multicolumn{2}{|c|}{ High } & \multicolumn{2}{|c|}{ Sufficient } & \multicolumn{2}{|c|}{ Average } & \multicolumn{2}{|c|}{ Low } \\
\hline Groups & 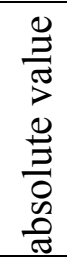 & $a^{\circ}$ & 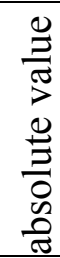 & $a^{\circ}$ & 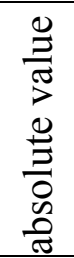 & $a^{0}$ & 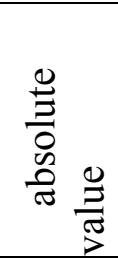 & $\begin{array}{l}{ }^{\circ} \\
. \Xi\end{array}$ \\
\hline Control & 22 & 8,1 & 67 & 24,8 & 135 & 50 & 46 & 17,1 \\
\hline Experimental & 16 & 5,8 & 53 & 19,4 & 145 & 52,9 & 60 & 21,9 \\
\hline
\end{tabular}

As evident from the table, a majority of future masters showed an average level of formation of the motivational-personal component of readiness to ensure the quality of the educational process in preschool education institution.

Conclusions. The results of the empirical research confirm the need to organize and conduct work on raising the level of motivation and personal component of MA students' readiness to ensure the quality of educational process in preschool education institution.

Further research will focus on identifying levels of cognitive-search activity, activityoperational, and reflexivity-evaluative components of readiness to ensure the quality of educational process in the preschool educational institutions and development of pedagogical technology for its formation in the process of professional master training.

\section{REFERENCES (TRANSLATED \& TRANSLITERATED)}

1. Shapar, V. B. (2004). Psykholohichnyi tlumachnyi slovnyk [Psychological dictionary]. Kharkiv: Prapor [in Ukrainian].

2. Vitvytska, S.S. (2011). Teoretychni i metodychni zasady pidhotovky mahistriv v umovakh stupenevoi osvity [Theoretical and methodological basis of training masters in a multi-level education]. Extended abstract of Doctor's thesis. Zhytomyr: Vyd-vo ZhDU [in Ukrainian].

3. Zahorodnia, L.P. (2018). Kryterii, pokaznyky ta rivni sformovanosti hotovnosti mahistriv do zabezpechennia yakosti osvitnioho protsesu v zakladi doshkil'noi osvity [Criteria, indicators and levels of formation of readiness of master's degrees to ensure the quality of the educational process in institutions of preschool education]. Pedahohichna osvita: 
teoriia i praktyka - Pedagogical Education: Theory and Practice, 25 (2-2018), 65-71. Part 1. Kamianets-Podilskyi. DOI: 10.32626/2309-9763.2018-25.65-71 [in Ukrainian].

4. Zadorozhna-Kniahnytska, L.V. (2017). Orhanizatsiino-metodychni umovy deontolohichnoi pidhotovky menedzheriv osvity $\mathrm{u}$ vyshchykh navchalnykh zakladakh [Organizational and methodological conditions of deontological training of education managers in higher educational institutions]. Naukovi zapysky Ternop. nats. ped. un-tu imeni Volodymyra Hnatiuka. Seriia: Pedahohika - Scientific notes Ternop. nat. ped. univ. named after Volodymyr Hnatiuk. Series: Pedagogy, 3, 90-98. DOI: 10:25128/2415-3605.17.3.12 [in Ukrainian].

5. Zadorozhna-Kniahnytska, L.V. (2018). Obgruntuvannia zmistu y struktury deontolohichnoi kompetentnosti menedzhera osvity [Substantiation of the content and structure of the deontological competence of the education Manager]. Journal "ScienceRise: Pedagogical Education", 2 (22), 24-28. DOI: 10.15587/2519-4984.2018.124456 [in Ukrainian].

6. Zakorchenna, H.M. (2000). Pidhotovka studentiv do pedahohichnoho menedzhmentu v doshkilnii osviti [Students' training for pedagogical management in preschool education]. Extended abstract of candidate's thesis. Odesa [in Ukrainian].

7. Zhyhir, V.I. (2017). Osoblyvosti profesiinoi pidhotovky menedzheriv osvity v umovakh mahistratury [Features of professional training of managers of education in the conditions of magistracy]. Retrieved from ea.donntu.edu.ua:8080/bitstream/123456789/.../1/zhigir.pdf. [in Ukrainian].

8. Zhyhir, V.I. (2013) Sutnist i zmist profesiino vazhlyvykh yakostei osobystosti menedzhera osvity [The essence and content of professionally important qualities of the education Manager's personality]. Visnyk Luhanskoho natsional'noho universytetu imeni Tarasa Shevchenka. Pedahohichni nauky - Luhansk Taras Shevchenko National University Journal. Pedagogical science, 10(3), 113-124. Luhansk [in Ukrainian].

Received: January 10, 2019

Accepted: March 11, 2019

\section{Емпіричне дослідження сформованості мотиваційно-особистісного компонента готовності магістрів до забезпечення якості освітнього процесу в закладі доикільної освіти.}

У статті представлено результати емпіричного дослідження стану сформованості мотиваційноособистісного компонента готовності магістрів до забезпечення якості освітнього процесу в закладі дошкільної освіти, проведеного автором. Свроінтеграційні процеси, щчо відбуваються в Украӥні та зміни в початковій школі актуалізують проблему формування готовності магістрів дошкільної освіти до забезпечення якості освітнього процесу в дошкільній установі. 3 метою з'ясування стану

сформованості мотиваційно-особистісного компонента ГДЗЯОП в закладі дошкільної освіти 8 майбутніх магістрів був дібраний комплекс методів діагностики, відповідно до визначених нами компонентів, критеріїв і показників, а саме: методика вивчення мотивацї професійної діяльності

(К. Замфір в модифікації А. Реана, Н. Бадмаєвої), методика визначення Я-концепиії (методика Кемпбелла SCC), визначення місия компонентів ГДЗЯОП в ЗДО в ї̈ структурі, анкетування, методи математичної статистики.

3'ясовано, щуо найкраще в магістрантів сформована мотивація професійної діяльності- у $52 \%$ респондентів виявлено ї̈ високий рівень. Проте $70 \%$ магістрантів не усвідомлюють ролі мотивації, як складника спрямованості, в проиесі формування їхньої готовності до забезпечення якості освітнього процесу в ЗДО. Магістранти засвідчили достатній і середній рівні сформованості Я-конщепџї та не чіткі иіннісні орієнтації і професійні потреби. Окрім того, студенти назвали далеко не всі основні особистісно-професійні якості директора ЗДО, віддаючи перевагу моральним. У більшості магістрантів виявлено середній рівень сформованості мотиваційно-особистісного компонента готовності до забезпечення якості освітнього процесу в закладі дошкільної освіти, щуо засвідчує необхідність організащії і проведення роботи з підвищення його рівня.

Ключові слова: магістри дошкільної освіти, мотиваційно-особистісний компонент готовності до забезпечення якості освітнього процесу в закладах дошкільної освіти, методи діагностики, критерії готовності, рівні сформованості. 